\title{
〔31〕ピリジン環を主鎖に有するポリエステルの合成
}

(1966 年 9 月 5 日受理)

\section{橋本静信* ・長砂泰彦*}

要 旨 ピリジン環を有する 2 価のアルコールおよびジカルボン酸を原料とする重縮合を行なった。 2,6 -位にメチロール基を有する 2,6 -ジメチロールピリシンと脂肪族ジカルボン酸シメチルェステル と溶融重合を行ない, 次いで, イソシンコメロン酸シメチルおよびシフェニルエステル, 2,6 -シメチ ルー3，5-ジェトキシカルボニルピリシンと各種ジオールの溶融重合を試みた。 また, これらイソシン コメロン酸, 2,6 -ジメチルー3,5-ピリシンカルボン酸扰よび 3,5 -ピリジンジカルボン酸のジクロ ライドを用いる界面重合を試みた。そして,これらの生成物の融点, 粘度, 可紡性および溶解性などを 検討した。その結果, 界面重合で得た生成物は, $300^{\circ} \mathrm{C}$ 以上の融点を持つ高い溶液粘度のポリマーであ った。

\section{1. 緒言}

ピリシン環を主鎖にもつポリェステルは，ポリマー内 に窒素原子を有するために染色性のすぐれたものが期待 される。ピリシン環を主鎖に有するポリェステルについ

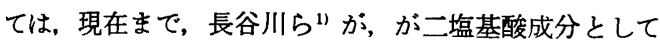
ジピコリン酸ジェニルェステルを用い, エチレンクリ コール, ビスフェノールAなどと溶融重合を行ない, $\mathrm{mp} 162 \sim 171^{\circ} \mathrm{C}, 280 \sim 290^{\circ} \mathrm{C}$ の着色性のものを得てい る。また, J. Gordon ら²) の USP でイソシンコメロン 酸の使用で記されてあるか，合成例, 物性について全く 報告がない。さらに大河原ら ソシンコメロン酸シメチルとェチレングリコールとの溶 融重合では, 黒色物質あるいは低融点物しか得られてい ない。しかし, J. W. Stimpson ら5) のイソシンュィロ ン酸ジロライドとビスフェノールAなどとの界面重合 では, 高融点のポリマーを得ている。

そこで筆者らは, ピリシン環を有するポリェステルに いてさらに検討するために，まず，2 価アルコールと して 2,6-ルチシンより合成される 2,6 -ジメチロール ピリシンを用い, 二塩基酸シメチルエステル類との溶融 重合を行なった。また, ピリシンカルボン酸類として は, アルデヒドュリシンの酸化で得られるイソシンュメ ロン酸のジチルエステル, ジフェニルエステルおよび ジクロライドを合成し，これと各種ジオールとの溶融, 界面重合を行なった。また, アセト酷酸エチルから比較

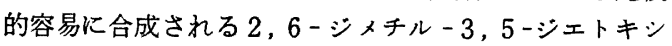
カルボニルピリシンとそのジクロライドを合成した。ま た, 2,6 -ジメチル - 3, 5-ピリシンカルボン酸の酸化, 脱炭酸で得られる 3,5 -ピリジンジカルボン酸のシクロ ライドを合成した。そして,これらを前者と同しょら に, 各種シオールと溶融, 界面重台を試みた。

* 同志社大学工学部工業化学教室 (京都市上京区鳥丸 今出川)

\section{2. 実験方法}

\section{1 原料合成}

\subsubsection{2,6-ジメチロールピリジン}

2,6-ジメチロールピリシンは, V. Bockelheide ら の方法に従って合成した。すなわち，2，6-ルチシンン 氷酢酸溶媒中過酸化水素水にょり，2，6-ルチジン-Nオキサイドとし，これを無水酢酸との反応で 2 -アセト キシメチルー6-メチルピリシンとし，さらに無水酢酸を 作用させ， 2，6-ビス（アセトキシメチル）ピリシンソ, bp $114 \sim 115^{\circ} \mathrm{C} / 0.16 \mathrm{mmHg}$ (文献値), bp $135 \sim 139^{\circ} \mathrm{C}$ $10.3 \mathrm{mmHg}$ ) を得た。次に, この 2,6 -ビス（アセトキ シメチル）ピリシンを濃塩酸と還流して加水分解し, 反 応物を乾固した後, 再びメタノールに溶解し, このメタ ノール溶液をアンパーライトIRA-400に通し, 留出物 を槞固した後, ベンゼンーメタノール混合溶液より再結 晶し, 細長い板状白色結晶 $\mathrm{mp} 110 \sim 112^{\circ} \mathrm{C}$ (文献値 ${ }^{6}$ ) $114 \sim 115^{\circ} \mathrm{C}$ ）である 2,6 -ジメチロールピリシンを得 た（全収率 $5 \%$ )。

\subsection{2 イソシンコメロン酸とその誘導体}

a . イソシンコメロン酸 : パラアルデヒド, アンモ= ア水扣よび触媒の酢酸アンモニウムから常法により合成 したアルデヒドュリジンの $172 \sim 175^{\circ} \mathrm{C}$ (文献値") $172 \sim$ $174^{\circ} \mathrm{C}$ ）の留分を村橋らの方法に基いて酸化した。すな わち, アルデヒドュリシン $12.1 \mathrm{~g}(0.1 \mathrm{~mol})$, 濃硫酸 $156 \mathrm{~g}(1.5 \mathrm{~mol})$ および触媒の覀セレン酸または金属七 レン $3 \mathrm{~g}$ を $280 \sim 290^{\circ} \mathrm{C} て ゙$ 約 1 時間反応した。反応の終 了は, 反応で生成する水の補集量で決定した。冷却後反 応物に少量の水を加え, セレンを口過して回収した後, 口液を 300 ～ $500 \mathrm{cc}$ の水に注ぎ 1 夜冷蔵庫中に放置し, 黄色, または淡赤色の結晶 $11.7 \mathrm{~g}$ （収率 $70 \%$ ）を得た。 これを $2 N$ の水酸化ナトリウム水溶液に溶かし活性炭で 脱色した徭，2N の硫酸で中和して沈殿を析出させ，さ らに水より再結晶を行ない, $\mathrm{mp} 253 \sim 254^{\circ} \mathrm{C}$ (文献値 ${ }^{7)}$ $\mathrm{mp} 253^{\circ} \mathrm{C}$ ) の白色結晶を得た。 
b. イソシンコメロン酸シメチル：イソシンコメロン 酸 $38 \mathrm{~g}(0.23 \mathrm{~mol})$, メタノール $400 \mathrm{cc}$ に, 濃硫酸 $40 \mathrm{~g}$ を加方，10時間加熱逗流した。イソシンコメロン酸は, 加熱すればすぐに溶解して黄色溶液となった。反応後, 大部分のメタノールを留去して水中に注ぎ, 炭酸ソーダ 水溶夜を加えて弱アルカリ性にし, 冷却後, 未反応のイ ソシンコメロン酸をロ過により除去した。生成物は, メ タノールから再結晶して $\mathrm{mp} 162 \sim 163^{\circ} \mathrm{C}$ (文献值 ${ }^{8)} \mathrm{mp}$ $164^{\circ} \mathrm{C}$ ) の白色針状結晶 $33.6 \mathrm{~g}$ (収率 $75.5 \%$ ) を得た。

c . イソシンコメロン酸ジクロライト：イソシンコメ ロン酸 $30 \mathrm{~g}(0.18 \mathrm{~mol})$ に塩化チオニル $150 \mathrm{~g}(1.26$ $\mathrm{mol}$ )を加光, 水浴上で 14 時間加熱逻流した。加熱後, 䄪 14 時間で反応層は完全に均一となった。反応後, 減 王下で過剩の塩化チオニルを留去し, 残留物を脱水乾燥 した石油エーテルから再結晶して $\mathrm{mp} 52 \sim 53^{\circ} \mathrm{C}$ (文献 值") $53 \sim 54^{\circ} \mathrm{C}$ ) の微黄色針状結晶 $18 \mathrm{~g}$ （収率 $49 \%$ ）を 得た。

d. イソシンコメロン酸ジフェニル：イソシンコメロ ン酸 $50 \mathrm{~g}(0.3 \mathrm{~mol})$ と塩化チオニル $210 \mathrm{~g}(1.76 \mathrm{~mol})$ を水浴上で 14 時間加熱還流し，過鄱の塩化チオニルを 留去した残留物の粗イソシンコメロン酸ジクロライドに フェノール $90 \mathrm{~g}(0.96 \mathrm{~mol})$ を加え, 水浴上で 1 時間, その後, 塩化水素ガスが発生しなくなるまで約 $150^{\circ} \mathrm{C}$ で30分間加熱した。過剩のフェノールを減圧下で留去

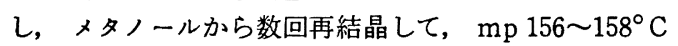
(文献值 ${ }^{10)} 156^{\circ} \mathrm{C}$ ) の白色結晶 $76 \mathrm{~g}$ (収率 $75 \%$ ) を得た。

2.1.32,6-ジメチル-3,5-シシエトキシカルボニル ピリジンとその誘導体

a. 2,5 -ジメチル-3,5-ジエトキシカルボニルピ リジン $6^{\text {8) }}$ : アセト䣫酸エチル, ホルマリンおよびアン モニアから常法に従って, Hantzsch エステルを得,これ を硝酸酸化し, 減圧蒸留によって $150 \sim 158^{\circ} \mathrm{C} / 5 \mathrm{mmHg}$ （文献値 ${ }^{11} 170 \sim 172^{\circ} \mathrm{C} / 8 \mathrm{mmHg}$ ）の留分を取り,アルコ 一ルから再結晶して, $\mathrm{mp} 70 \sim 72^{\circ} \mathrm{C}$ (文献值 ${ }^{12} \mathrm{mp} 72^{\circ}$ C)の無色針状結晶を得た。

b. 2, 6-ジメチル-3，5-ピリジンジカルボン酸 : 2, 6 -シ்メチー3, 5 -ジェトキシカルボニルピリジン を常法に従って水酸化ナトリウムのアルコール溶液で加 水分解し, 塩酸で中和して白色沈殿を得た。これを水か ら再結晶して, $\mathrm{mp} 315^{\circ} \mathrm{C}$ (文献值 ${ }^{12)} \mathrm{mp} 316^{\circ} \mathrm{C}$ ) の白 色針状結晶を得た。

c. 2,6 -ジメチル-3,5-ピリジンジカルボン酸シ クロライト: 2,6-ジメチルー3,5-ピリシンジカルボ ン酸 $30 \mathrm{~g}(0.154 \mathrm{~mol})$ に塩化チオニル $200 \mathrm{~g}(1.68$ $\mathrm{mol}$ ）を加兄, 水浴上で 14 時間加熱還流した。反応後, 減正下で過剩の塩化チオニルを留去し, 残留物を少量の 四塩化炭素に溶解して石油エーテル中に注ぎ再沈殿し, $\mathrm{mp} 90 \sim 92^{\circ} \mathrm{C}$ (文献値 ${ }^{12} \mathrm{mp} 90 \sim 93^{\circ} \mathrm{C}$ ) の黄色結晶
$23 \mathrm{~g}$ (収率 $65 \%$ ）を得た。

3.1.43,5-ピリジンジカルポン酸とその馀導体

a. 3,5-ピリジンカルポン酸: 2,6 -ジメチルー3, 5 -ピリシンジカルボン酸 $39 \mathrm{~g}(0.2 \mathrm{~mol})$ と濃硫酸 $206 \mathrm{~g}$ (2.1 mol) 扰よび触媒の金属セレン $3 \mathrm{~g}$ を 260 $280^{\circ} \mathrm{C}$ で約 30 分間反応させた。反応の終了は, イソシ ンコメロン酸の合成の場合と同じょうに反応で生成する 水の捕集量によって決定した。冷却後, 少量の水を加 え, セレンを回収した後, 口液を $500 \mathrm{cc}$ の水中に注ぎ, 1 夜冷蔵庫中に放值し, 黒かつ色の沈殿を得た。これを $2 N$ の水酸化ナトリウム水溶液に溶かして活性炭て脱色 し，2Nの硫酸で中和して白色結晶を得た。次に，2，6位のカルボキシル基を完全に脱炭酸させるために, 酷酸 中で 1 時間加熱還流した。これを水から再結晶し, $\mathrm{mp}$ $329 \sim 331^{\circ} \mathrm{C}$ (文献值 $\left.{ }^{14}\right) 323^{\circ} \mathrm{C}$ ) の白色結晶 $17.5 \mathrm{~g}$ （収 率 $52.5 \%$ ）を得た。この生成物中の不純物を調へるた めに, ペーパークロマトグラフィーを行なった。展開剤 として $5 \%$ アンモニア水を使用し, 検出はブロムクレジ ールグリンを用いた。結果は, $R_{f}=0.77(2,6$-ジメ チルー3, 5 -ピリジンジカルボン酸は, $R_{f}=0.80$ でケイ 光を持つ）以外の不純物は，検出されなかった。それゆ えに, 上記の生成物は, ほぼ純粋な 3,5 -ピリジンジカ ルボン酸であると考えられる。また, 純度の決定に, カ ルボキシル基の定量を非水溶媒系で行なった。すなわち, 試料を DMFに溶かし，指示薬にチモールブルーを用い， アルコラートのアルコール溶夜で滴定して深青色に変わ ったところを終点とした。この分析の結果, 計算值と分 析値の一致を見た。

b. 3,5-ピリジンジカルボン酸ジクロライト： 3 ， 5 -ピリシンシシカルボン酸 $20 \mathrm{~g}(0.12 \mathrm{~mol})$ に塩化チオニ ル $150 \mathrm{~g}(1.26 \mathrm{~mol})$ を加え, 水浴上で14 時間加熱還流 した。反応後, 過剩の塩化チオニルを留去した残留物を 脱水乾燥した石油エーテルから再結晶して, $\mathrm{mp} \mathrm{58 \sim 60^{ \circ }}$ $\mathrm{C}$ (文献値 ${ }^{14)} \mathrm{mp} 66^{\circ} \mathrm{C}$ ) の無色ウロコ片状結晶 $14.5 \mathrm{~g}$ （収率 60\%）を得た。

\subsection{5 脂肪族ジカルボン酸ジメチルエステル}

a. シュウ酸ジメチル：メタノールより再結晶を行な い, $\mathrm{mp} 52 \sim 53^{\circ} \mathrm{C}$ (文献値 $52.5 \sim 53.5^{\circ} \mathrm{C}$ ) のものを使 用。

b. コハク酸ジメチル : bp $77^{\circ} \mathrm{C} / 3 \mathrm{mmHg}, n_{D}^{21.6}$ 1.4187 (文献値 $n_{D}{ }^{18.3} 1.4190$ ) のもの使用。

c.アジピン酸ジメチル : bp $108 \sim 109^{\circ} \mathrm{C} / 3 \mathrm{mmHg}$, $n_{D}{ }^{21.5} 1.4276$ (文献值 $n_{D}{ }^{20} 1.4286$ ) のもの使用。

\subsection{6 ジオール類}

a 、エチレンタリコール，1，2-プロピレンタリコー ルおよびジエチレンクリコール：市販一級品を無水硫酸 ナトリゥムで乾燥し, 粗蒸留を行なったものに, 金属ナト リウム $(1 \mathrm{~g} / 100 \mathrm{ml})$ を加之，隇圧蒸留したものを使用。 
エチレングリコール : $\mathrm{bp} 106^{\circ} \mathrm{C} / 24 \mathrm{mmHg}$ (文献値 bp $197.9^{\circ} \mathrm{C} / 760 \mathrm{mmHg}$ )

1, 2-プロピレングリコール : bp 104 $105^{\circ} \mathrm{C} / 30 \mathrm{~mm}$ $\mathrm{Hg}$ (文献値 bp $188 \sim 189^{\circ} \mathrm{C} / 760 \mathrm{mmHg}$

ジエチレンクリコール : bp $143 \sim 144^{\circ} \mathrm{C} / 23 \mathrm{mmHg}$ (文献値 bp $244 \sim 245^{\circ} \mathrm{C} / 760 \mathrm{mmHg}$ )

b . ハイトロロキノンおよびレソルシン : 市販一級品を 純水より再結晶を行なったものを使用。

ハイトロロキノン : $\mathrm{mp} 177 \sim 180^{\circ} \mathrm{C}$ (文献值 $172.3^{\circ} \mathrm{C}$ ) の白色結晶。

レソルシン : $\mathrm{mp} 109 \sim 110^{\circ} \mathrm{C}$ （文献值 $\mathrm{mp} 110^{\circ} \mathrm{C}$ )の 白色結晶。

c. ヒヒスフェノールAおよびテトラフロムビスフェノ 一ル A : 市販一級品を精製したトルエンより再結晶を行 なったものを使用。

ビスフェノールA : mp $156 \sim 158^{\circ} \mathrm{C}$ （文献值 155〜 $\left.156^{\circ} \mathrm{C}\right)$ の白色針状結晶。

テトラフロムヒススフノールA : mp $181 \sim 182^{\circ} \mathrm{C}$ の 無色斜方形結晶 (文献值 $\mathrm{mp} 162 \sim 163^{\circ} \mathrm{C}$ )

\section{1 .7 重合䖪媒}

a. テトラプロピルチタネート : Bradley'5) らのテト ラェチルチタネートの合成法を参考にした。すなわち, 脱水したベンゼン中に, 四塩化チタンとイソプロピルフ ルコールを加え, 脱塩酸剤として乾燥アンモニアガスを 導入して合成した。窒素気流中，2 回減圧蒸留して得た bp $82^{\circ} \mathrm{C} / 3 \mathrm{mmHg}$ （文献値 ${ }^{15)} 116^{\circ} \mathrm{C} / 10 \mathrm{mmHg}$ ）の留分 を使用。

Table 1. Polycondensation of 2,6-dimethylol pyridine with aliphatic dicarboxylic acid dimethylesters.

2,6-Dimethylolpyridine : $1.112 \mathrm{~g}(0.008 \mathrm{~mol})$

Zinc acetate $\quad: 0.001 \mathrm{~g}$ b . その他の重合触媒 : 酢酸亜鉛, 酢酸カルシウム, 三酸化アンチモン, トリフェニルホスファイトおよびブ チルスズオキサイドなどは，それぞれ市販一級品を使用。

\section{2 重合方法}

2.2.12,6-ジメチロールピリジンと脂肪族ジカル ポン酸ジメチルとの溶融重合

2,6 -ジメチロールピリジンと等モルの脂肪族ジカル ボン酸ジメル扰よび触媒を内径 $15 \mathrm{~mm}$, 長さ $300 \mathrm{~mm}$ の枝付重合管に入れ，これに還元銅で除酸素し，シリカ ゲルおよび五酸化リンで乾燥した窒素ガスを通じながら $120 \sim 140^{\circ} \mathrm{C}$ で数時間加熱し，まず，低重合度のポリエ ステルを合成した後，水流ポンプおよび真空ポンプ（1

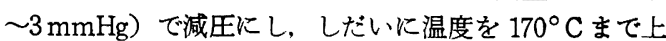
昇して反応を行なった。

2.2 .2 ピリジンジカルボン酸ジエステルとジオール との溶融重合

ピリジンジカルボン酸ジェステルに約 2.5 倍モルの脂 肪族シオール（芳香族ジオールの場合は等モル）および 触媒を加え，2.2.1 と同じ重合装置を用い，重合温度お よび触媒を種々変化させて反応を行なった。

2.2 .3 ピリジンジカルボン酸ジクロライトと芳香族 ジオールとの界面重合

ピリシンジカルボン酸ジクロライド $0.01 \mathrm{~mol}$ の $50 \mathrm{cc}$ 有機溶媒溶液を芳香族ジオール $0.01 \mathrm{~mol}$ と水酸化ナト リウム $0.02 \mathrm{~mol}$ (ハイドロキノンおよびレゾルシンの場 合に炭酸水素ナトリウムを使用)の $50 \mathrm{cc}$ 水溶液に, 激し くかきまぜながら 1 度に加え，10～30分間反応を続けた。

\begin{tabular}{|c|c|c|c|c|c|c|c|c|}
\hline \multirow[b]{2}{*}{ No. } & \multirow[b]{2}{*}{$\begin{array}{l}\text { Dimethylesters } \\
\mathrm{g} \text { (mol) }\end{array}$} & \multicolumn{3}{|c|}{ Polycondensation condition } & \multicolumn{4}{|c|}{ Polymers } \\
\hline & & $\begin{array}{l}\text { Temp. } \\
\left({ }^{\circ} \mathrm{C}\right)\end{array}$ & $\begin{array}{l}\text { Pressure } \\
(\mathrm{mmHg})\end{array}$ & $\begin{array}{l}\text { Time } \\
(h r)\end{array}$ & Appearance & $\begin{array}{l}\text { Melting } \\
\text { point } \\
\left({ }^{\circ} \mathrm{C}\right)\end{array}$ & $\begin{array}{l}\text { Reduced } \\
\text { specific } \\
\text { viscosity* }\end{array}$ & $\begin{array}{l}\text { Melt } \\
\text { spinnable } \\
\text { property }\end{array}$ \\
\hline 1 & $\begin{array}{l}\text { Dimethyl oxalate } \\
0.944(0.008)\end{array}$ & $120 \sim 140$ & 760 & 3.0 & $\begin{array}{l}\text { Brown red } \\
\text { viscous solid }\end{array}$ & - & - & - \\
\hline 2 & $\begin{array}{l}\text { Dimethyl succinate } \\
1.168(0.008)\end{array}$ & $\begin{array}{c}120 \sim 135 \\
130 \sim 140 \\
160 \\
160 \sim 170\end{array}$ & $\begin{array}{r}760 \\
40 \\
40 \\
3\end{array}$ & $\begin{array}{l}3.0 \\
7.5 \\
4.0 \\
3.5\end{array}$ & $\begin{array}{l}\text { Light orange } \\
\text { opaque solid }\end{array}$ & $120 \sim 122$ & 0.11 & - \\
\hline 3 & $\begin{array}{l}\text { Dimethyl adipate } \\
1.584(0.008)\end{array}$ & $\begin{array}{l}130 \sim 140 \\
130 \sim 140 \\
130 \sim 140\end{array}$ & $\begin{array}{r}760 \\
40 \\
4\end{array}$ & $\begin{array}{r}10.0 \\
10.0 \\
8.0\end{array}$ & $\begin{array}{l}\text { Brown } \\
\text { viscous } \\
\text { solid }\end{array}$ & - & - & - \\
\hline
\end{tabular}

* Measured in $0.5 \mathrm{wt} \%$ sym-tetrachloroethane solution at $30^{\circ} \mathrm{C}$ 
Table 2. Melt polycondensation of pyridine dicarboxylic acid with diols.

\begin{tabular}{|c|c|c|c|c|c|c|c|c|c|c|}
\hline \multirow[b]{2}{*}{ No. } & \multirow{2}{*}{$\begin{array}{l}\text { Diester } \\
\mathrm{g}(\mathrm{mol})\end{array}$} & \multirow{2}{*}{$\begin{array}{l}\text { Diol } \\
\mathrm{g}(\mathrm{mol})\end{array}$} & \multirow{2}{*}{$\begin{array}{l}\text { Cata- } \\
\text { lyst }\end{array}$} & \multicolumn{3}{|c|}{$\begin{array}{l}\text { Polycondensation } \\
\text { condition }\end{array}$} & \multicolumn{4}{|c|}{ Polymers } \\
\hline & & & & $\begin{array}{l}\text { Temp. } \\
\left({ }^{\circ} \mathrm{C}\right)\end{array}$ & $\begin{array}{l}\text { Pressure } \\
(\mathrm{mmHg})\end{array}$ & $\begin{array}{c}\text { Time } \\
(\mathrm{hr} r)\end{array}$ & Appearance & $\left|\begin{array}{l}\text { Melting } \\
\text { point } \\
\left({ }^{\circ} \mathrm{C}\right)\end{array}\right|$ & $\mid \begin{array}{l}\text { Reduced** } \\
\text { specific } \\
\text { viscosity }\end{array}$ & $\begin{array}{l}\text { Melt } \\
\text { spinnable } \\
\text { property }\end{array}$ \\
\hline 1 & \begin{tabular}{|l} 
Dimethyl \\
isocincho- \\
meronate \\
$1.67(0.0085)$
\end{tabular} & $\begin{array}{l}\text { Ethylene } \\
\text { glycol } \\
1.55(0.025)\end{array}$ & a & $\left|\begin{array}{c}110 \\
110 \sim 140 \\
140 \sim 150\end{array}\right|$ & $\begin{array}{r}760 \\
30 \\
2\end{array}$ & $\begin{array}{r}25 \\
2 \\
3\end{array}$ & Brown solid & $|202 \sim 214|$ & 0.05 & + \\
\hline 2 & " & "I & a & $\begin{array}{c}120 \\
120 \\
120 \sim 180\end{array}$ & $\begin{array}{r}760 \\
30 \\
2\end{array}$ & $\begin{array}{r}35 \\
2 \\
3\end{array}$ & $" 1$ & $235 \sim 241$ & 0.06 & + \\
\hline 3 & $" 1$ & $" \prime$ & a & $\begin{array}{l}110 \\
110 \\
110\end{array}$ & $\begin{array}{r}760 \\
30 \\
2\end{array}$ & $\begin{array}{r}40 \\
8 \\
2\end{array}$ & $\begin{array}{l}\text { Light red } \\
\text { solid }\end{array}$ & $85 \sim 122$ & 0.03 & - \\
\hline 4 & " & " & - & $\begin{array}{l}110 \\
135 \\
135 \\
135 \\
\end{array}$ & $\begin{array}{r}760 \\
760 \\
30 \\
2\end{array}$ & $\begin{array}{r}16 \\
12 \\
2 \\
3\end{array}$ & Brow solid & $135 \sim 145$ & 0.04 & + \\
\hline 5 & $\begin{array}{l}\text { Diphenyl } \\
\text { isocincho- } \\
\text { meronate } \\
1.595(0.005)\end{array}$ & " & a & $\begin{array}{l}120 \\
120 \\
120\end{array}$ & $\begin{array}{r}760 \\
30 \\
2\end{array}$ & $\begin{array}{r}15 \\
10 \\
8\end{array}$ & $\begin{array}{l}\text { Yellowish } \\
\text { solid }\end{array}$ & $166 \sim 173$ & 0.06 & + \\
\hline 6 & "I & " & $\mathrm{b}$ & $\begin{array}{l}120 \\
120 \\
120\end{array}$ & $\begin{array}{r}760 \\
30 \\
2\end{array}$ & $\begin{array}{r}15 \\
10 \\
8 \\
\end{array}$ & " & $170 \sim 198$ & 0.06 & + \\
\hline 7 & "I & " & c & $\begin{array}{l}120 \\
120 \\
120\end{array}$ & $\begin{array}{r}760 \\
30 \\
2\end{array}$ & $\begin{array}{r}15 \\
10 \\
8\end{array}$ & "I & $175 \sim 185$ & 0.06 & + \\
\hline 8 & $\begin{array}{l}\text { Diphenyl } \\
\text { isocincho } \\
\text { meronate } \\
3.19(0.01)\end{array}$ & $\begin{array}{l}\text { 1, 2- } \\
\text { Propylene } \\
\text { glycol } \\
5.0(0.065)\end{array}$ & $\mathrm{b}$ & $\begin{array}{l}120 \\
120 \\
120\end{array}$ & $\begin{array}{r}760 \\
30 \\
2\end{array}$ & $\begin{array}{l}10 \\
10 \\
10\end{array}$ & $\begin{array}{l}\text { Yellowish } \\
\text { viscous } \\
\text { liquid }\end{array}$ & - & - & - \\
\hline 9 & " & $\begin{array}{l}\text { Diethylene } \\
\text { glycol } \\
5.0(0.047)\end{array}$ & $\mathrm{b}$ & $\begin{array}{l}120 \\
120 \\
137 \\
\end{array}$ & $\begin{array}{r}760 \\
30 \\
2 \\
\end{array}$ & $\begin{array}{l}10 \\
10 \\
30\end{array}$ & "I & - & - & - \\
\hline 10 & " & $\begin{array}{l}\text { BisphenolA } \\
2.28(0.01)\end{array}$ & $\mathrm{b}$ & $\begin{array}{c}160 \sim 180 \\
180 \\
180 \sim 250\end{array}$ & $\begin{array}{r}760 \\
20 \\
2\end{array}$ & $\begin{array}{l}1 \\
1 \\
2\end{array}$ & Brown solid & $200 \sim 262$ & 0.40 & + \\
\hline 11 & $\begin{array}{l}\text { 2,6-Dimeth- } \\
\text { yl-3,5-di- } \\
\text { carboethoxy } \\
\text { pyridine } \\
2.51(0.01) \\
\end{array}$ & $\begin{array}{l}\begin{array}{l}\text { Ethylene } \\
\text { glycol }\end{array} \\
1.55(0.025)\end{array}$ & $\mathrm{b}$ & $\begin{array}{c}180 \\
180 \\
180 \sim 200\end{array}$ & $\begin{array}{r}760 \\
20 \\
2\end{array}$ & $\begin{array}{l}4 \\
2 \\
8\end{array}$ & $\begin{array}{l}\text { Yellowish } \\
\text { solid }\end{array}$ & $130 \sim 135$ & 0.20 & + \\
\hline 12 & "I & $\begin{array}{c}\text { 1,2-Propy- } \\
\text { leneglycol } \\
5.0(0.065)\end{array}$ & $\mathrm{b}$ & $\begin{array}{c}180 \\
180 \\
180 \sim 240 \\
\end{array}$ & $\begin{array}{r}760 \\
20 \\
2\end{array}$ & $\begin{array}{r}10 \\
6 \\
8\end{array}$ & " & $30 \sim 45$ & 0.08 & - \\
\hline 13 & " & $\begin{array}{l}\text { Diethylene } \\
\text { glycol } \\
5.0(0.047)\end{array}$ & $\mathrm{b}$ & $\begin{array}{c}180 \\
180 \\
180 \sim 260\end{array}$ & $\begin{array}{r}760 \\
20 \\
2\end{array}$ & $\begin{array}{r}10 \\
6 \\
8\end{array}$ & $\begin{array}{l}\text { Brown } \\
\text { viscous } \\
\text { solid }\end{array}$ & - & - & - \\
\hline
\end{tabular}

* a : $\mathrm{Ca}(\mathrm{OAc})_{2} 0.003 \mathrm{~g}, \mathrm{Sb}_{2} \mathrm{O}_{3} 0.001 \mathrm{~g}$

$\mathrm{b}: \mathrm{Zn}(\mathrm{OAc}) 0.003 \mathrm{~g}, \mathrm{Sb}_{2} \mathrm{O}_{3} 0.001 \mathrm{~g}$

c : Tetrapropyltitanate $(0.5 \mathrm{~mol}$ of $40 \%$ benzene solution) 2 drops

** Measured in $0.5 \mathrm{wt} \%$ sym-tetrachloroethane solution at $30^{\circ} \mathrm{C}$ 
生成したボリマーは，よく水洗し，乾燥した。

\section{3 融点測定法}

十分乾燥し細かく确いたポリマーを柳本製作所微量融 点測定器を用いて測定した。

\section{4 粘度測定法}

溶剈に精製したテトラクロルエタンあるいは市販特級 の $95 \%$ 濃硫酸を用い，オストワルド型粘度計で $30 \pm$ $0.01^{\circ} \mathrm{C}, 0.5 \mathrm{~g} / 100 \mathrm{ml}$ の濃度で測定した。

\section{5 溶融紡系性試験}

重合物を再度融点以上に加熱して溶融し, 細いガラス 棒をつけて引き上げ，系を引くかを調べ紡糸性を検討し た。

\section{3. 実験結果と考察}

$3.12,6$ - シメチロールピリジンと脂 肪族ジカルボン酸ジメチルとの溶融重合

2,6 -ジメチルロールピリシンと種々の 脂肪族シカルボン酸シメチルとの溶融重合 の重合条件扰よび生成物の外観, 融点, 粘 度を Table 1 に示した。

これらのらち、コハク酸シメチルを用い

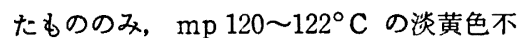
透明固体を得た。しかし，その他のものは 着色性の粘稠物であった。触媒には, 酢酸 亜鉛の他にテトラブロピルチタネート，卜 リフェニルホスファイトおよびブチルスズ オキサイドを使用したが，良好な結果は得 られなかった。

3.2 ピリジンジカルボン酸ジェステル とジオールとの溶融重合

イソシンコメロン酸シメチル, ジフェニル エステルおよび 2,6 -ジメチルー3,5-シ A.
エトキシカルボニルピリシンと各種ジオールの溶融重合て の重合条件および生成物の外観, 融点, 粘度を Table 2 に示した。

イソシンコメロン酸ジメチルとェチレングリコールに 触媒として酢酸カルシウムと三酸化アンチモンの混合触 媒を用いた場合, 重合温度が $110^{\circ} \mathrm{C}$ (トルェン蒸気浴)で は，重合はあまり進まず生成物は $\mathrm{mp} 85 \sim 122^{\circ} \mathrm{C}$ ，還元 比粘度 0.03 のやや赤味をおびた不透明固体であった。 初期重合温度を $120^{\circ} \mathrm{C}$, 最終温度を $150^{\circ} \mathrm{C}$ で反応させ たものは, 反応中に漸次固化し, $\mathrm{mp} 202 \sim 214^{\circ} \mathrm{C}$, 還元 比粘度 0.05 のかっ色固体を得た。また温度を上昇させ 最終温度が $200^{\circ} \mathrm{C}$ 以上に達したものは，分解を起こし 黒変し,ピリジン臭が認められた。また無触媒でも同じ

Table 3. Interfacial polycondensation of isocinchomeronic acid dichloride with bisphenol A. Isocinchomeronic acid dichloride: $2.04 \mathrm{~g}(0.01 \mathrm{~mol})$

Bisphenol A

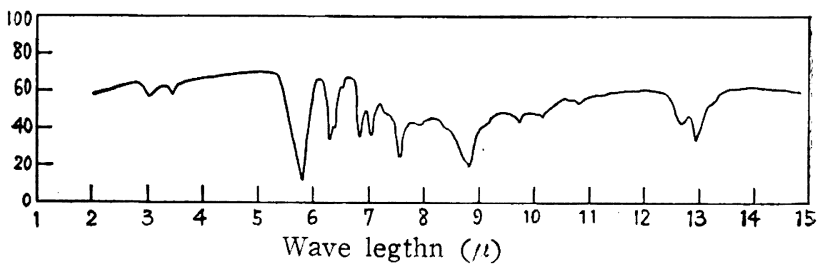

Fig. 1. IR spectrum of polymer formed by melt polycondensation of 2, 6-dimethylol-pyridine with dimethyl succinate.

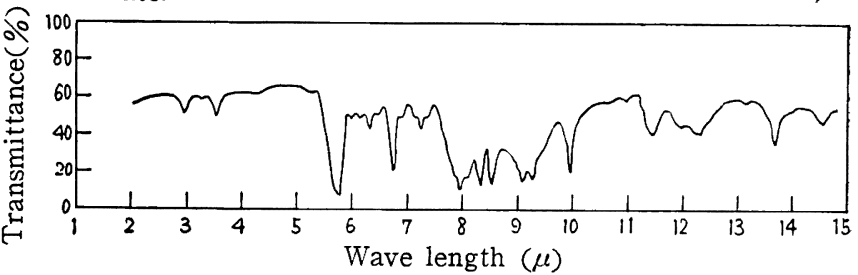

Fig. 2. IR spectrum of polymer formed by interfacial polycondesation of isocinchomeronic dichloride with bisphenol 
Table 4. Interfacial polycondensation of pyridine dicarboxylic

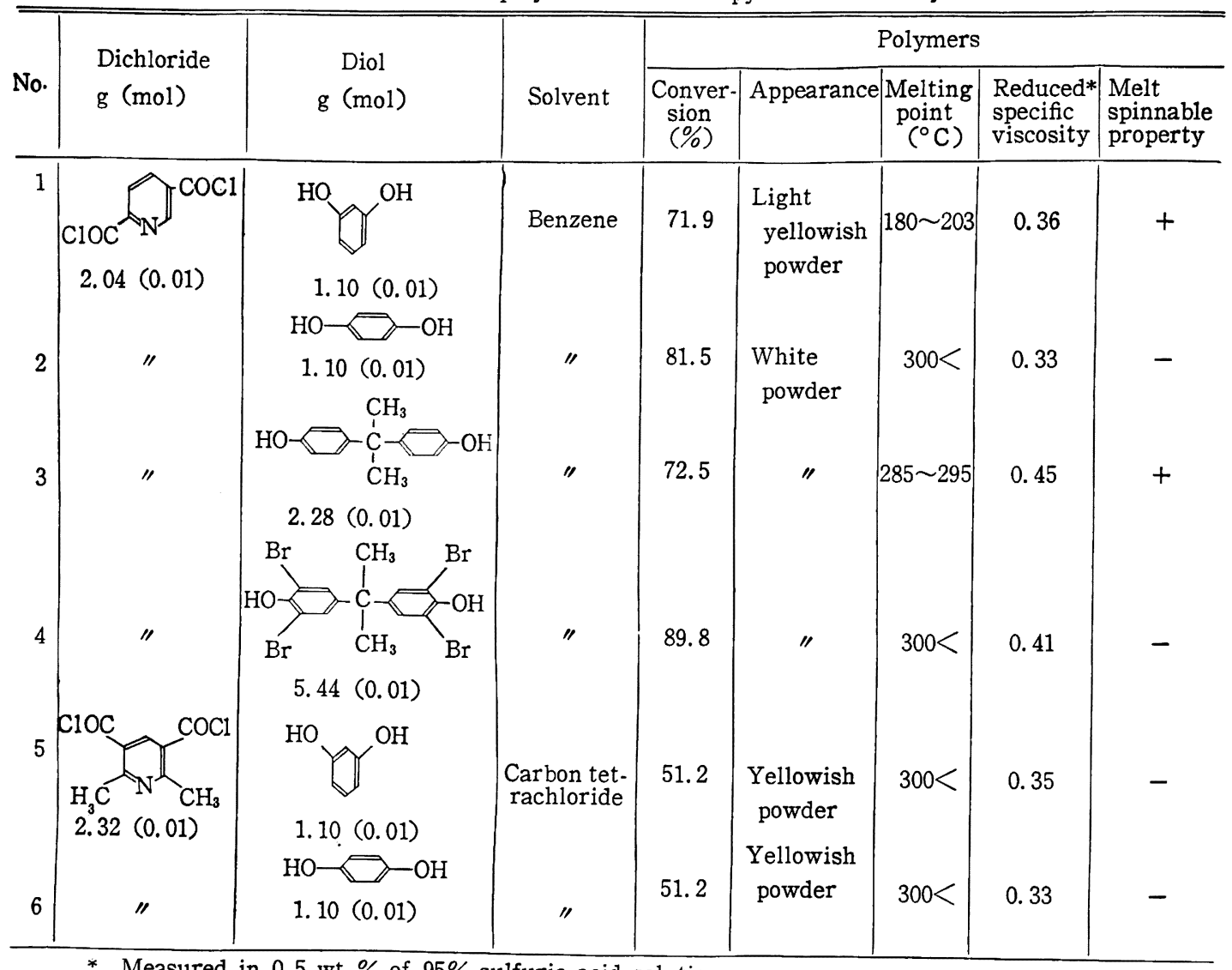

* Measured in $0.5 \mathrm{wt} \%$ of $95 \%$ sulfuric acid solution

よらに着色した。このようにインシンコィ ロン酸シメチルは，やや熱に不安定である のであまり温度を上昇させることは困難で ある。インシンコメロン酸シメチルよりも やや熱安定性が良好で反応性も良いと見ら れるインシンコメロン酸ジフェニルでは, 触媒に酢酸カルシウムと三酸化アンチモ ン，酢酸严鉛と三酸化アンチモンおよびテ トラプロピルチタネートの 3 種を用いた が, いずれも生成物は少し黄色を帯びた固

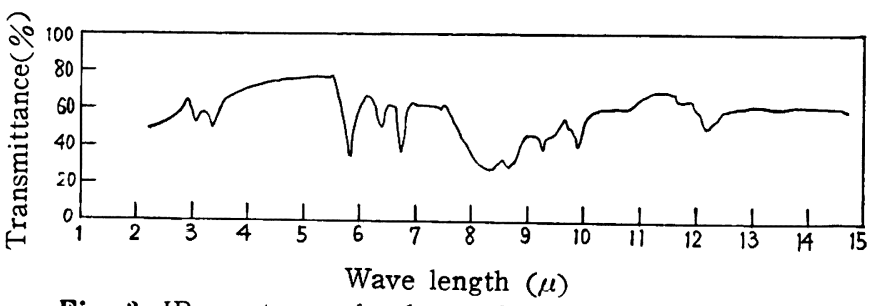

Fig. 3. IR spectrum of polymer formed by interfacial polycondensation of 2, 6-demethyl-3, 5-pyridine dicarboxylic acid dichloride with bisphenol A.
体であり, 還元比粘度は, $0.06, \mathrm{mp} 170^{\circ} \mathrm{C}$ 前後のもの あった。Table 2 の No. 4 と No. 5 を比較してもよくわ かるよらにインシンコメロン酸ジフェニルの方がイソシ ンコメロン酸シメチルよりも反応が速く，また，着色度 も少なく、熱的にやや安定だ推論される。しかし，シ フェニルェステルを用いた場合です, 反応温度を上昇さ せると着色度が増大する傾向が認められた。1，2-プロ ピレングリコールやジェチンクリリュールをジオール成
分として用いた場合には, Table 2 で明らかなように良 好なものは得られなかった。また,ビスフェノールAを 用いた場合でも，溶融するために温度を上昇させたので， やはり着色が激しかった。

ピリジンカルボン酸は, $\alpha$ 位のカルボキシル基の方が $\beta$ 位のカルボキシル基よりも脱炭酸しやすいことが知られ ている。そこで次に，2，6-位にメチル基，3，5-位に カルボェトキシ基を持つ 2,6 -ジメチルー3,5-ジェト 
acid dichlorides with aromatic diols.

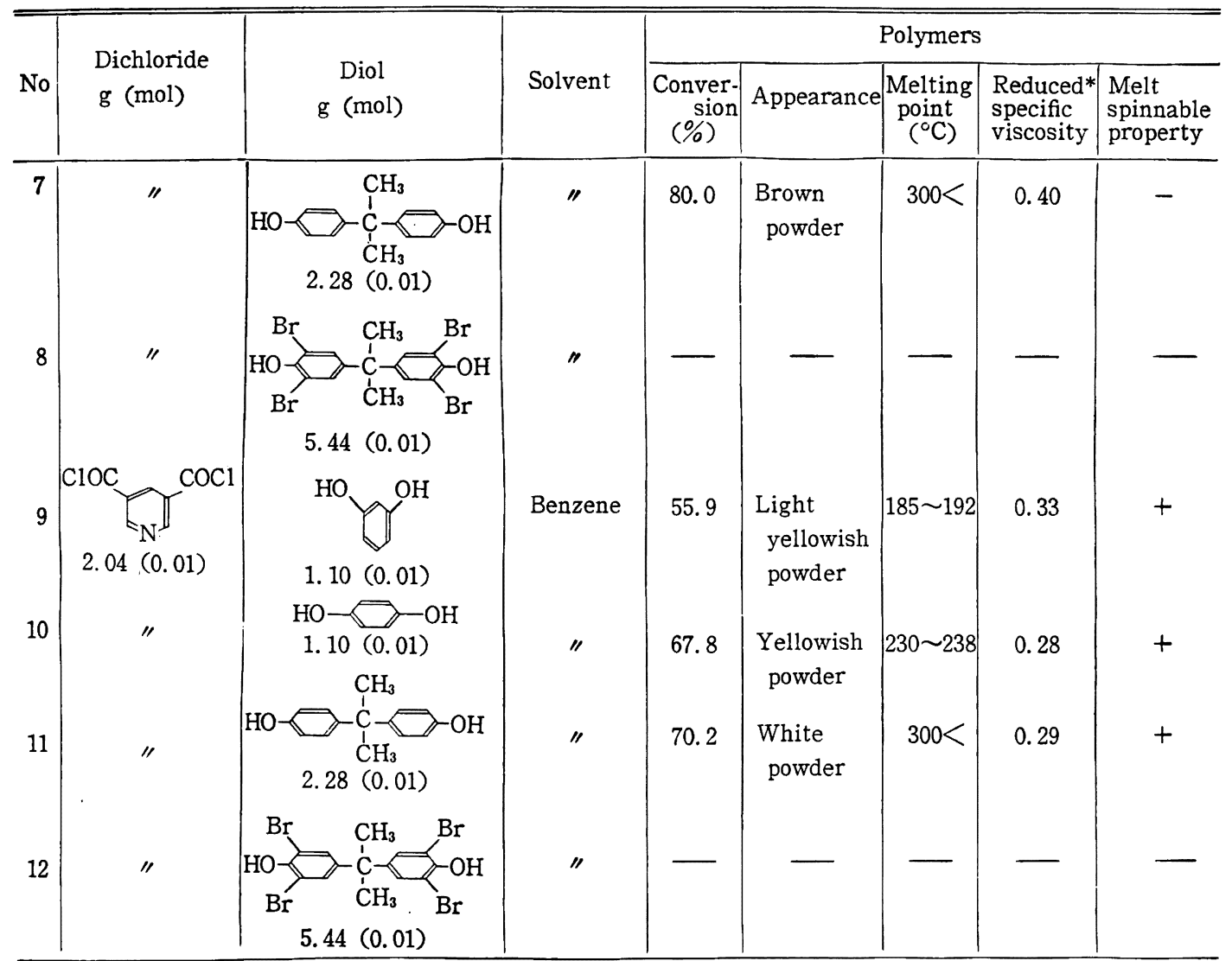

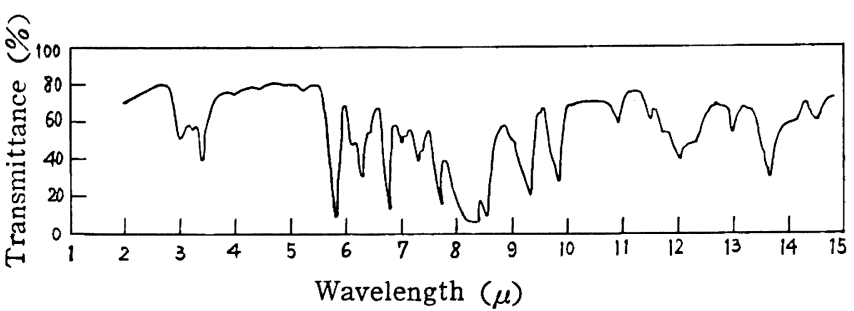

Fig. 4. IR Spectrum of polymer formed by interfacial polycondensation of 3,5- pyridine dicarboxylic acid dichloride with bisphenol $\mathrm{A}$.

キシカルボニルピリシンを二塩基酸成分に用い，まず，エ

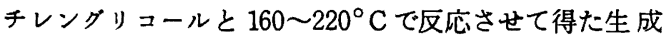
物は $\mathrm{mp} 130 \sim 135^{\circ} \mathrm{C}$ でインシンコメロン酸ジエステル を使用した場合よりも還元比粘度は大きく 0.20 の黄色 固体であった。これもまた反応温度を $260^{\circ} \mathrm{C}$ 以上にすれ ば, 分解して黒変した。以上の上らに, $\beta$ 位にのみカ ルボキシル基を持つピリシンジカルボン酸ジェステルで も. 高温では分解することがわかった。1，2ープロピ
レングリコールやジェチレングリコール とも, 同じ重合条件で重合を試みたが低 融点物しか得られなかった。

\section{3 ピリジンジカルボン酸ジロラ}

イトと芳香族ジオールとの界面重合

溶融重合では，以上の上らにかなり高 温にしないと重合は進まないし，また高 温では,ピリシンンカルボン酸類は不安定 で分解しやすいことがわかった。そこで 常温付近で重合する界面重合反応を行な った。

イソシンコメロン酸ジクロライドとビスフェノール A との界面重合に护ける有機溶媒の効果は Table 3 に示 した。有機溶媒としてはペンゼンが最も有効であり，ま た界面活性剤を加えた方が，より高重合度のポリエステ ルが得られた。次に 3 種のピリシンジカルボン酸シクロ ライドと 4 種の芳香族シオールとの界面重合を行なった。 その結果は, Table 4に示した。この 3 種のインシンコ 
Table 5. Solubility of polymer.

\begin{tabular}{l|c|c|c|c|c|c|c|c|c|c|c|c|c|c|c}
\hline \hline \multicolumn{1}{c|}{ Polymer No. } & 2 & - & 2 & - & 5 & 2 & -11 & 3 & - & 2 & 4 & - & 7 & 4 & -11 \\
\hline \multicolumn{1}{c}{ Condition* } & $\mathrm{A}$ & $\mathrm{B}$ & $\mathrm{A}$ & $\mathrm{B}$ & $\mathrm{A}$ & $\mathrm{B}$ & $\mathrm{A}$ & $\mathrm{B}$ & $\mathrm{A}$ & $\mathrm{B}$ & $\mathrm{A}$ & $\mathrm{B}$ \\
\hline Water & - & - & - & - & - & - & - & - & - & - & - & - \\
Methanol & - & - & - & - & - & - & - & - & - & - & - & - \\
Benzene & - & - & - & - & - & - & - & - & - & - & - & - \\
Toluene & - & - & - & - & - & - & - & - & - & - & - & - \\
$n$-Hexane & - & - & - & - & - & - & - & - & - & - & - & - \\
Acetone & - & - & - & - & - & - & - & - & - & - & - & - \\
Acetic acid & - & + & - & + & - & - & - & + & - & - & & - \\
Anisol & - & + & - & + & - & - & - & + & - & \pm & - & - \\
Nitrobenzene & - & + & - & + & - & - & - & + & - & \pm & - & + \\
Phenol & + & + & + & + & + & + & + & + & \pm & \pm & + & + \\
$m$-Cresol & + & + & + & + & + & + & + & + & \pm & \pm & + & + \\
Pyridine & - & + & - & + & - & + & - & + & - & \pm & - & \pm \\
Carbon tetrachloride & - & - & - & - & - & - & - & - & - & - & - & - \\
Chloroform & - & + & - & + & - & + & + & + & - & - & - & - \\
Tetrachloroethane & + & + & + & + & + & + & + & + & - & - & - & + \\
Conc. sulfuric acid & + & & + & & + & & + & & + & & + & \\
& & & & & & & & & & & & \\
\hline
\end{tabular}

*A: Room temperature. B: Boiling point of solvent, + : Soluble. \pm : Partly soluble. - : Insoluble

メロン酸ジクロライド, 2,6 -ジメチル 3,5 -ピリシン ジカルポン酸ジロライド扰よび 3,5 -ピリシンンジ ルボン酸シクロライドのうち，2，6-ジメチル-3，5ピリシンジカルボン酸ジクロイドから得たポリエステ ルは, 酸クロライドがペンゼンに溶解しにくかったので 四塩化炭素を溶媒に用いたか; 生成物は黄色またはかっ 色で着色が大きかった。また，2，6-ジメチルー3,5ピリシンジカルボン酸シクロライドおよび 3,5 ーピリシ ンジカルボン酸ジクロライドとテトラブロムビスフェノ 一ルAとの反応では, ポリエステルは生成しなかった。 これは，立体障害により重縮合反応が妨げられたものと 推定される。

\section{4 ポリマーの赤外吸収スペクトル}

生成したポリエステルのうち，4 種類のポリエステル について $\mathrm{KBr}$ 法により赤外吸収スベクトルを測定した。 結果は, Fig. 1〜4 亿示した。図より明らかなようにい ずれもェステル結合の強い吸収が，1735〜 $1745 \mathrm{~cm}^{-1} に$ あった。

\section{5 ポリマーの溶解性}

ポリマーの溶解性は Table 5 に示した。表から明ら かなよらK, 水, メタノール, ベンゼン, n一へキサン拉 よびアセトンなどには不溶である。しかし，ピリシン環 をボリマー内に持つために濃硫酸には，完全に溶解し た。
付 記：本研究は, 高分子学会第 15 回年次大会 1966年 5 月, 名古屋）に打いて発表したものである。

\section{文・献}

1）長谷川正木, 鈴木房枝：工化，66，1230 (1963)

2) J. Gordon et al. : USP 2551731 (1951)

3）篠原弘之, 一宮康祐, 吉村羍四郎, 大河原 信 : 高化, 15, 839 (1958)

4) A. Lupu, M. Opris: Rev. Chim (Bucharest), 10, 607 (1959) [C $A, 57,15334(1962)]$

5) J. W. Stimpson: Brit. P 853730 (1959)

6) V. Bockelheide et al.: J. Am. Chem. Soc., 76, 1286 (1954)

7）村橋俊介：阪大産研報文, 7,127 (1950)

8) Beilsten Handbuch d. Org. Chem., 22, 153, H. Meyer, F. Staffen: Monatsh., 34, 521 (1913)

9) Beilstein Handbuch d. Org. Chem., 22, 153; Weider, Herzig: Monatsh., 6, 987 (1885)

10) Beilstein Handbuch d. Org. Chem., EII, 22, 153; H. Meyer: Rec. Trav. Chim., 44, 327

11) "Org. Syntheses Coll", II, 214 (1943)

12) Beilstein Handbuch d. Org. Chem., 22, 163; Engelmann: Ann., 231, 50 (1872) 
13）大河原 信, 笹岡 勁, 井本英二：工化，65，156 (1962)

14) Beilstein Handbuch d. Org. Chem., 22, 160; 15) D. C. Bladley: J. Chem. Soc., 1955, 721 (1955)

H. Meyer, Tropsch: Monatsh., 35, 209,

\title{
The Synthesis of Polyesters Containing Pyridine Ring in Main Chains
}

\author{
By Shizunobu Hashimoto* and Yasuhiko Nagasuna*
}

The preparation and properties of polyesters from 2,6-dimethylol pyridine with aliphatic dicarboxylic acids and pyridine dicarboxylic acid derivatives with diols by melt or interfacial polycondensation have been studied. Polyesters from 2,6-dimethylol pyridine with dimethylesters of aliphatic dicarboxylic acids were prepared by melt polycondensation. Polyesters from dimethyl isocinchomeronate, diphenyl isocinchomeronate, or 2, 6-dimethyl-3, 5-dicarbobethoxy pyridine with diols were prepared by melt polycondensation. All-aromatic polyesters were prepared from three kinds of pyridine dicarboxylic acid dichlorides with aromatic diols by interfacial polycondensation. The physical properties of these polyesters prepared, such as melting point, solution viscosity, melt spinnable property, and solubility, were measured. The all-aromatic polyesters prepared by interfacial polycondensation had high solution viscosity and rather high melting point, which is above $300^{\circ} \mathrm{C}$.

* Department of Applied Chemistry, Doshisha University (Karasuma-imadegawa, Kamikyo-ku, Kyoto) 